\title{
The effects of a Web-based training in an instructional systems design approach on teachers' instructional design behavior
}

Citation for published version (APA):

Hoogveld, B., Paas, F., Jochems, W., \& Van Merriënboer, J. (2001). The effects of a Web-based training in an instructional systems design approach on teachers' instructional design behavior. Computers in Human Behavior, 17(4), 363-371. https://doi.org/10.1016/S0747-5632(01)00013-9

DOI:

10.1016/S0747-5632(01)00013-9

Document status and date:

Published: 01/07/2001

Document Version:

Peer reviewed version

Please check the document version of this publication:

- A submitted manuscript is the version of the article upon submission and before peer-review. There can be important differences between the submitted version and the official published version of record. People interested in the research are advised to contact the author for the final version of the publication, or visit the DOI to the publisher's website.

- The final author version and the galley proof are versions of the publication after peer review.

- The final published version features the final layout of the paper including the volume, issue and page numbers.

Link to publication

\section{General rights}

Copyright and moral rights for the publications made accessible in the public portal are retained by the authors and/or other copyright owners and it is a condition of accessing publications that users recognise and abide by the legal requirements associated with these rights.

- Users may download and print one copy of any publication from the public portal for the purpose of private study or research.

- You may not further distribute the material or use it for any profit-making activity or commercial gain

- You may freely distribute the URL identifying the publication in the public portal.

If the publication is distributed under the terms of Article $25 \mathrm{fa}$ of the Dutch Copyright Act, indicated by the "Taverne" license above, please follow below link for the End User Agreement:

https://www.ou.nl/taverne-agreement

Take down policy

If you believe that this document breaches copyright please contact us at:

pure-support@ou.nl

providing details and we will investigate your claim.

Downloaded from https://research.ou.nl/ on date: 26 Apr. 2023 
Running head: EFFECTS OF A WEB-BASED ISD TRAINING

The Effects of a Web-Based Training in an Instructional Systems Design Approach on Teachers' Instructional Design Behavior

Albert W. M. Hoogveld, Fred Paas, Wim M. G. Jochems, Jeroen J. G. van Merriënboer

Open University of the Netherlands

Educational Technology Expertise Center 


\begin{abstract}
$\underline{\text { Abstract }}$
Deficiencies in instructional design skill have been identified as a possible cause for the problems teachers of Dutch Polytechnics experience in designing competency-based education. This research investigates the effects of an Instructional Systems Design (ISD) training on teachers' instructional design behavior. Thirty-six teachers from 16 Dutch Teacher Training Colleges received 20 hours of web-based training either in an ISD based condition or in an experience-based design condition (EXP). In the ISD condition teachers were trained to apply the 4C-ID model of van Merriënboer (1997), in the EXP condition the teachers were trained to optimize their own approach. The results supported the hypotheses, indicating that the ISD-based training resulted in a higher quality of design and was evaluated more positive than the EXP approach. These findings suggest that training in an ISD approach can effectively support teachers' instructional design strategies.
\end{abstract}


The Effects of a Web-Based Training in an Instructional Systems Design Approach on Teachers' Instructional Design Behavior

Teachers of Dutch Polytechnics are reported experiencing problems in translating newly stated curriculum principles into concrete study-units (HBO-Raad, 1996). In a recent study, Hoogveld, Paas, Jochems, and Van Merriënboer (2001) identified deficiencies in the teacher's instructional design skills as a possible cause for these problems. The recently revised curricula of most Dutch Polytechnics rely heavily upon 'learning-process oriented' educational principles, such as thematic project-based education, case-based learning, problem-based learning and competency-based learning. Also, the interest of these institutions of higher education in distributing education over the web has increased greatly with the rapid growth and technical development of the internet. The design approach of the teachers, however, did not experience a concomitant change accordingly and is still mainly based on the teaching principle of ‘knowledge transmission' (Vermunt \& Verloop, 1999). The new learning-process oriented teaching principles, preferably applied in a web-based environment, require an instructional design approach which enables the teachers to program learning activities through which complex professional skills can be mastered (Reigeluth \& Nelson, 1997). Hoogveld et al. (2001) argue that teacher's conventional experienced-based design approach, focusing on elaboration and structuring of domain content, is not effective in that respect. According to Tennyson (this issue), competency in ISD methodology can be considered as one of the three basic core knowledge areas that needs to be mastered by teachers to be able to apply learning-process oriented teaching principles in Internet based learning environments.

This study is based on the assumption that Instructional Systems Design (ISD) approaches can effectively support the teachers in the design of learning tasks for their students in the new curriculum. This hypothesis is based on the holistic character of the ISD approach. This means that it emphasizes the whole problem-solving cycle: Analysis, Design, Development, Implementation and Evaluation. Also, the scope of design of the ISD approach is not only formed by the content, and content structure, but also by the structure of the entire curriculum as 
a 'system'. Moallem (1998) and Klauer (1997) have shown that teachers are not well acquainted with ISD approaches and, consequently, do not frequently use them in the design of study units. The exploratory study of Hoogveld et al. (2001) showed that teachers' conventional design approach particularly shows serious gaps in the cycle's phases of Analysis and Evaluation (see also Rowland, 1992). In choosing an ISD model that can be used to prepare the teachers for their design task in the new curriculum, the acceptance of such a model by the teachers is a crucial element. Teachers do not like very prescriptive design methods, because they are trained to evaluate all preparation for lessons or study units in terms of successes in classroom interaction. This is part of their personal theories or beliefs (Moallem, 1998). As stakeholders of curriculum design processes, teachers always want to be able to directly 'preview' the consequences of decisions to prepare instruction. For this reason the ISD procedures applied, should be shorter than the classical ADDIE procedures and prototype these consequences permanently (Reigeluth \& Nelson, 1997). Finally, when used by teachers, a training in the ISD approach should not only cover macro-curriculum levels, but should also support micro-curriculum designs (Klauer, 1997). Applying these criteria, classical ISD models like the Dick and Carey (1996) model, the Romiszowski (1981) model, the Gagné and Briggs (1974) model, or the Leshin, Pollock and Reigeluth (1992) model, seem less appropriate to base the total ISD training upon.

In this study, Van Merriënboer's (1997) Four-Component Instructional Design Model (4C/ID model) was chosen as an appropriate ISD approach. This model is considered one of the few ISD models that is learning-process oriented (Clark \& Estes, 1999). In addition, the model takes a middle position between prescriptive empirical and descriptive analytical approaches, enables micro-level design, and gives the designer insight and control of the consequences of the design process. The model focuses on the programming of concrete learning tasks in cases or task classes in such a way, that the skills can be acquired in the context of the 'whole' professional task. As such, it can be considered as supportive for developing competency-based education (Vermunt \& Verloop, 1999). Van Merriënboer's work on the 4C/ID approach was 
judged by the magazine Training as an 'incomparable way to dissect complex skills and create efficient learning designs' (Zemke, 2000).

Relating this to the previously mentioned acceptance problems, the deficiencies in teachers' instructional design skill can be eliminated by a training in the 4C/ID methodology since this methodology is relatively short and non prescriptive, and because it focuses on the factors underlying the deficiencies, namely, inadequate analysis and diagnosis.

The research question of this study is stated as follows: Can a training in an ISD approach improve teachers' instructional design behavior? It is hypothesized that teachers who are trained in an ISD-design approach, will show superior design skills as compared to teachers who were trained to optimize their conventional, experience-based, approach. It is also hypothesized that after the training, the ISD-trained teachers will show a more positive attitude towards this method as an effective support in skill-based instructional design than teachers trained to optimize their conventional design approach have towards that method. To investigate these assumptions, both the process and the product of design are studied.

\section{Method}

\section{$\underline{\text { Participants }}$}

Participants were 36 instructors (27 men and 9 women) from 16 Dutch Primary Teacher Training Colleges. These colleges are charged with the training of future elementary or primary school teachers.

Materials and procedures

The two levels of the independent variable Instructional Design Training were ISD training condition and EXP training condition. The training in the ISD condition was based on the Four-Component Instructional Design model of van Merriënboer (1997). In the EXP condition the participants received training to optimize their own experience-based instructional design approach.

Before the start of the training the participants received a Preliminary Measurement Scale, a questionnaire which they had to fill in and return. The participants were randomly 
assigned to the two conditions. Within each condition two groups of 9 persons were created. During a condition-specific kick-off meeting, the participants were briefed about general aspects of the experiment and about aspects that were specific to their training condition. With regard to the training websites, arrangements were made to ensure that each participant only had admission to the condition-specific training web. This was controlled by admission to closed websites of the Open University of the Netherlands' learning environment 'Studienet'. The participants received a web based training of 20 hours. Both the ISD and the EXP condition consisted of four one-week training blocks equally divided across the following subjects: 1) Introduction, 2) Evaluation of design problems with study units, recently made by the participants, 3) Design approach for creating learning tasks for new study units, and 4) How to integrate the just learned approach in the curriculum of participants' institution.

Both training conditions were set up as a task-guided individual study on the Internet, and comprised four to six different tasks per training block. Each task consisted of worked-out problem cases and offered opportunities to practice with design problems. Individual feedback, help, and coaching was provided in the websites e-mail facility during the exercises. Two expert tutors were available to provide feedback, help, and coaching to the participants during the training period of the experiment. Each tutor took care of one ISD group and one EXP group. Before the experiment a tutoring protocol was developed and both tutors were trained to use the protocol. Immediately after the training period, all participants received the same design task as an assignment. The design task required the participants to make a complete global design for a study unit that should be usable in their educational program. The participants had one month to complete the design assignment. For both conditions, instructions and design output-tools were available on a design-support web on the Internet. From this web, the participant could always get admission to all of the information of the training website, (s)he had admission to. All participants who finished the experiment were given a certificate and a small gift. In addition. the best design in each condition was rewarded with a book. 
The condition-specific aspects for the ISD and EXP conditions are as follows: In the ISD condition Block 2 dealt with the function of evaluation in an ISD design approach and contained exercises to plan, work out and evaluate implemented designs. In the EXP condition Block 2 consisted of reflection on problems with recently constructed and implemented study units and of exercising sound evaluation principles. In the ISD condition, Block 3 focused on the design of learning tasks, following van Merriënboer's 'whole-task approach' (van Merriënboer, 1997) and resulted in a blueprint of a series of lessons or study unit. Block 3 in the EXP condition consisted of working out learning tasks, based on a clear description of the learning objectives, a clear explication of instructional strategies, and of defining the concrete output of the learning tasks. Much attention was given to the optimizing of the coherence between these three activities by reflection. Block 4 in the ISD condition focused on 'macro-level sequencing', that is the application of the 4C/ID approach on the curriculum level. In the EXP condition Block 4 consisted of the reflection on the curriculum process.

To get more insight in the process character of the design tasks a one day follow-up session was organized for two participants of each condition. They were randomly chosen from the participants who had finished the design assignment. During this session the retention of the characteristics of the approach that was trained was determined, before and after a short retraining of the approach. This retraining was followed by two experimental design tasks of about 90 minutes in duration. The participants were also asked about the re-use of the approach before and after retraining and after completing the experimental tasks. The screen-input activities on the computer during the design activity were videotaped and coded in categories, corresponding the main elements of the design approach.

\section{$\underline{\text { Measures }}$}

Data were collected by means of a Preliminary Inquiry, the Evaluation of Approach Scale, the Expert's Assessment Scale, the Retention Test and the Videotaped design session. 
The Preliminary Inquiry served to collect three types of data: 1) general information (i.e., age, experience as teacher trainer, frequency of design of study tasks, and domain of design); 2) teacher's attitude towards solving instructional design problems, measured with a 20 item, 5point Likert scale; 3 ) teacher's recognition of, and attached importance to teaching concepts and roles that support process-oriented learning was measured by Hoogveld's et al. (2001) Role-Grid Scale.

The Expert's Assessment Scale was used to determine the quality of the designs that were produced by the participants after the training. It consisted of a general 9-item, 9-point scale, to assess the general design characteristics of each design, and a condition specific scale to assess the specific approach per condition.

The Evaluation of Approach Scale consisted of 50 items and was intended to measure the participants' opinion on the trained design approach. The items focused on the importance of the approach for the teacher trainers design practice. The scale included questions to control for the validity of the case.

The Retention Test used in the follow up experiment, consisted in each of the conditions of 13 multiple choice four item questions, discriminating between one correct and three wrong descriptions of the main characteristics of the approach. The sessions were videotaped and analyzed with The Observer Video-Pro software (Noldus Information Technology). In the ISD condition, the coding was based on the three main categories 'analysis', consisting of the subcategories hierarchical skill analysis, skill clustering and defining case types, 'working out learning tasks' consisting of the subcategories working out learning tasks and supportive information, and 'no input activity', which contained all non-screen activities (e.g., thinking, gazing, reading notes). The same main categories were distinguished in the EXP condition. The content of the category 'no input activity' was identical in both conditions. In the EXP condition, 'analysis' contained the subcategories of objectives, teaching concept, and teacher role. 
'Working out learning tasks' was based on the categories definition of study task and output of the task.

\section{Results}

The experts' judgements of the design quality and the participants' evaluation rating of the trained instructional design approach were taken as dependent variables. During the 2months experimental period a relatively large number of participants dropped out. From the 36 participants who started in this study, 31 returned the Preliminary Inquiry, 13 were able to complete the Evaluation of Approach Scale, and 9 finished the design assignment. Possible reasons for this large drop out will be given in the discussion section. The results are presented per measurement scale for the remaining participants.

The Preliminary Inquiry

Thirty-one participants responded to the preliminary inquiry, 18 in the ISD condition (14 men and 4 women) and 13 in the EXP condition ( 9 men and 4 women). The average experience of the participants as a teacher trainer was 10 years. The main reasons given for participation in the experiment were a general interest in being schooled in innovation of education, a specific interest in learning to design education, and an interest in tele-learning, schooling on the Internet. On the average, the respondents indicated that they were responsible for producing four study units per year. The attitude of the participants towards the design process of study units was measured with 14 Likert type items (Cronbach's Alpha =0.57). A Mann-Whitney U test (Siegel, 1956) showed that the median scores for attitude towards the design process did not differ between the EXP and the ISD conditions $(\underline{\mathrm{U}}=273, \underline{\mathrm{p}}>0.05)$.

The Role Grid Scale was comprised of 18 items to measure the amount of recognition, attached importance, and interest in training in six teaching roles that support process-oriented learning (see also Hoogveld et. al., 2001). Each items was expressed as a 9-point scale ranging from low (1) to high (9). The internal consistency of the items expressed as Cronbach's Alpha in this study was 0.89 . The results on the Role Grid Scale reveal that in general the teachers recognize themselves the least in the roles of diagnostician and evaluator. 
The Expert Assessment of Quality of Design Scale

The five designs produced by participants in the EXP condition and the eight designs from the ISD condition were assessed by two experts with help of the 15-item expert assessment scale for quality of design $($ Cronbach's Alpha $=.93)$. Cohen's Kappa for inter-rater reliability was 0.42 . The grand mean per condition per expert was calculated as the median of individual scores. A Mann-Whitney U test of these differences showed that the ratings of both experts for the ISD condition $(\underline{\mathrm{M}}=8.0)$ are significantly higher than the ratings of these experts for the EXP condition $(\underline{\mathrm{M}}=5.8 ; \underline{\mathrm{U}}=0, \underline{\mathrm{p}}<.05)$.

The Evaluation of Approach Scale.

All scores, indiscriminate of condition, of the 13 remaining participants on the 50 -item Evaluation of Approach scale were subjected to a data reducing Principal Component Factorial Analysis with varimax rotation. This analysis resulted in a first factor, contributing to greater than or equal to $45 \%$ of the total variance and second, third and fourth factors, each contributing to $10 \%$ of the total variance. The first factor included 16 questions that relate to the central evaluation question: What is the possible significance of this approach for my design practice? A Mann-Withney U-test on the median scores on these items revealed that the participants in the ISD condition rated the items of this first factor significantly higher than the participants in the EXP condition $(\underline{\mathrm{U}}=7 ; \underline{\mathrm{n} 1}=5, \underline{\mathrm{n} 2}=8, \underline{\mathrm{p}}<.05)$.

The follow up session.

Four persons participated in the follow-up session that was meant to get an impression of the differences in design processes as a function of the instructional design training condition. The analysis of the time spent on design activities of two cases in each condition offers some insight into the relative distribution of time across the different design activities. These data are presented in Table 1.

Insert Table 1 about here 
The results indicate that in the ISD condition substantially more time was spent on analysis activities and substantially less time on working out of study tasks than in the EXP condition. It should be noted that due to the low number of participants, no statistical tests were performed on these data.

\section{Discussion and Conclusions}

This study compared the effects of a web-based training in an Instructional Systems Design approach to a web-based training in an experience-based design approach on the resulting design behavior of Primary School Teacher Trainers. It was hypothesized that the resulting instructional designs of study units would be better in the ISD condition than in the EXP condition. Also, it was hypothesized that the ISD approach would be considered more relevant for their design practice than the EXP design approach. Both hypotheses were confirmed by the results.

In line with the expectations, the experimental follow-up sessions revealed a substantial difference in advantage of the ISD condition regarding the time spent on analysis activities during design of study units. This finding is consistent with the study of Hoogveld et al. (2001), in which the analysis and evaluation activities were identified as phases of the instructional design cycle to which teachers usually pay relatively little attention to. The current findings suggest that training in an ISD design approach can change this in such a way that analysis activities will receive more attention, which is considered to be an important condition for the improvement of instructional designs in the new competency-based curricula.

Unfortunately, the experiment suffered from a large number of drop outs. We believe that the web-based character of the training approach was a main cause for this problem. The training via the web gave the participants a lot of freedom in dividing their time between the different activities and over the relatively long time available for the training and test. For the experimenters it was difficult to control this. Also, the fact that during the training and test periods there was no opportunity for face to face contact between the participants and between 
the participants and the tutors, appeared to be demotivating for the participants. Future studies using web-based training should take appropriate actions to prevent people from dropping out, either by shortening the duration of the experiment or by trying to increase the participants' commitment to the experiment. One way to increase the participants' commitment could be to plan face to face meetings on a regular basis during the training period. Another possibility that we are currently investigating, is the use of a team approach. Working in teams is assumed to increase the social involvement of the individual team members. The training in the reported deficiencies in instructional design skill that have been identified as a possible cause for the problems teachers of Dutch Polytechnics experience in designing competency-based education, seem to help alleviate that. The teachers appear to pay more attention to the activities of analyzing and evaluating. These activities are considered important for the design of instruction in the new learning-process oriented curricula. It can be argued that the 4C/ID approach effectively supports the teachers in the design of learning tasks for their students in the new curriculum. However, more research in this area is needed. 
References

Clark, R. E. \& Estes, F. (1999). The development of authentic educational technologies. Educational Technology, 39(2), 5-16.

Dick, W., \& Carey, L. (1996). Instructional design: Theory and research. (Vol 2).

Hillsdale, NJ: Lawrence and Erlbaum.

Gagné, R. M., \& Briggs. L. J. (1974). Principles of instructional design. New York: Holt Rinehart and Winston.

HBO-Raad. (1996). Koers gekozen. Eindrapport van de vervolgvisitatiecommissie lerarenopleidingen basisonderwijs. [Course determined. Final follow-up report of visitation of Primary Teacher Training Colleges] (Sectorale kwaliteitszorg hbo, nr 28 en 33). Den Haag, The Netherlands: Voorlichtingsdienst HBO-Raad.

Hoogveld, A. W. M., Paas, F., Jochems, W. M. G., \& van Merriënboer, J. J. G. (2001) Exploring teachers' instructional design practices: Implications for improving teacher training. Manuscript submitted for publication.

Klauer, K. J. (1997). Instructional Design theory: A field in the making. In R. D. Tennyson, F. Schott, N. Seel, \& S. Dijkstra (Eds.), Instructional design: International perspectives (Vol. 1., pp. 447-455). Mahwah, NJ: London.

Leshin, C. B., Pollock, J., \& Reigeluth, C. M. (1992). Instructional design strategies and tactics. Englewood Cliffs, NJ: Educational Technology Publications.

Moallem, M. (1998). An expert teacher's thinking and teaching and instructional design models and principles: an ethnographic study. Educational Technology Research and Development, 46, 37-64.

Romiszowski, A. (1981) Designing Instructional Systems: Decision making in course planning and curriculum design. London, New York: Kogan Page.

Rowland, G. (1992). What do instructional designers actually do? An initial investigation of expert practice. Performance Improvement Quarterly, 2, 65-86. 
Siegel, S. (1956). Nonparametric statistics for the behavioral sciences. New York: Mc Graw- Hill Book Company, Inc.

Tennyson, R. D. (this issue). Defining core competencies of an instructional technologist. Computers in Human Behavior.

The Observer Video-Pro 4.0 [Computer Software]. (2000). Wageningen, The Netherlands: Noldus Information Technology.

Van Merriënboer, J. J. G. (1997). Training complex cognitive skills: A four-component instructional design model. Englewood Cliffs, NJ: Educational Technology Publications.

Vermunt, J. D., \& Verloop, N. (1999). Congruence and friction between learning and teaching. Learning and Instruction, 9, 257-280.

Zemke, R. (2000). Jeroen van Merriënboer, Quiet revolutionist. Training, 37, 44. 


\author{
Author Note
}

We thank all participants and institutes for their cooperation to the research. Special thanks go to Marcel Wigman and Jurjen Puls for their help with the admission policy to the Open University of the Netherlands's 'Studienet' facilities.

Correspondence concerning this article should be addressed to Bert Hoogveld, Educational Technology Expertise Center, Open University of the Netherlands, P.O. Box 2960, 6401 DL, Heerlen, The Netherlands. Electronic mail may be sent to Bert.Hoogveld@ou.nl. 
Table 1

Percentage of design time spent during the different categories of activities in the design task in the follow-up study as a function of condition. Activities

\begin{tabular}{|c|c|c|}
\hline \multirow[t]{2}{*}{$\begin{array}{l}\text { Categories of Design } \\
\text { Activities }\end{array}$} & \multicolumn{2}{|c|}{ Condition } \\
\hline & EXP & ISD \\
\hline Analysis & 39 & 54 \\
\hline Working out study tasks & 27 & 12 \\
\hline $\begin{array}{l}\text { Gazing, thinking, seeking } \\
\text { information }\end{array}$ & 34 & 34 \\
\hline
\end{tabular}

